\title{
OXYGEN TENSION OF TISSUES BY THE POLAROGRAPHIC METHOD. VI. EFFECT OF CHANGES IN POSITION ON OXYGEN TENSION OF THE SKIN OF TOES ${ }^{1}$
}

\author{
BY PHYLLIS G. WILLIAMS, HUGH MONTGOMERY, AND ORVILLE HORWITZ
}

\author{
(From the Vascular Section of the Robinette Foundation, Medical Clinic, Hospital of the \\ University of Pennsylvania, Philadelphia, Pa.)
}

(Submitted for publication March 16, 1953; accepted July 8, 1953)

\section{INTRODUCTION}

It is generally believed that the ischaemia of peripheral arterial occlusion is aggravated by raising the limb and relieved somewhat by lowering the limb. Patients with this condition often complain of foot pain while in bed. This is relieved by getting out of bed. If the head of the bed is raised or special devices are used to lower the leg (1) the pain of the foot is often relieved and the color of the foot improved. Conversely, a case recently came to our attention in which the foot of a patient, who had been confined to bed for a year because of a cerebrovascular accident, became gangrenous only two days after being elevated on two pillows.

Elevation of a normal limb decreases the arterial pressure within it, whereas dependency increases the pressure. Measurements of intra-arterial pressure show that the pressure varies directly with the vertical distance from the right atrium to the point of measurement (2). Such changes might be expected to cause predictable changes in limb blood flow, but the situation is complicated by concomitant changes in venous pressure $(3,4,5,6,7)$. In limbs with obstructive vascular disease the situation is still more complicated because of the marked reduction in arterial pressure which occurs distal to an obstruction (8).

Measurements of blood flow have been made in limbs at different levels of elevation and dependency; most investigators found the blood flow to increase when the limb is lowered and decrease when the limb is elevated $(9,10,11,12)$. One group found flow to decrease on dependence (13), and one to vary depending upon the preceding position (14). Some of the observations were complicated because the change in position of the limbs

1 This investigation was supported by a research grant (392 C3) from the National Heart Institute of the $\mathrm{Na}$ tional Institutes of Health, Public Health Service. was accompanied by changes in the disposition of the body, and by differences in muscular tension in the limbs (12). The various conclusions are probably dependent in part upon the degree and manner of changes of position, and upon the methods used to measure blood flow.

We have chosen to measure the oxygen tension of the skin of feet made severely ischaemic by peripheral arterial occlusion and to study changes in oxygen tension resulting from slight changes in the angle of the bed from the horizontal. Comparable studies were made on normals. Since there is no reason to suppose that a small change in position alters cutaneous metabolism, a change in oxygen tension of the skin may be taken as an index of a changed supply of oxygen, and presumably of other substances from the blood.

Some studies of prolonged maintenance of the dependent position were made in order to make sure that the tension changes are sustained.

Studies were made of normal and ischaemic limbs with unchanged position but with venous pressure increased by a cuff. The cuff pressure was equal to the hydrostatic pressure that had resulted, in the previous experiments, by lowering the limb.

\section{METHOD}

During the experiments the average room temperature was $26.7^{\circ} \mathrm{C}$., the extremes $20.4^{\circ} \mathrm{C}$. and $29.1^{\circ} \mathrm{C}$. The average variation of room temperature during an experiment was $1.6^{\circ} \mathrm{C}$., the greatest variation was $2.7^{\circ} \mathrm{C}$. A tilt table 6.5 feet in length was used. It was covered by a 1.5 inch mattress with a pillow. Enough blankets were provided to maintain a state of mild peripheral vasodilatation. The foot end of this table was raised or lowered without causing apprehension.

Four open tip platinum electrodes $(15,16)$ were used in each experiment. They were inserted into the skin at the base of the first, second, fourth, and fifth toes, in the areas where the thermocouples were placed. The method of estimating oxygen tension was that previously described 
TABLE I

Difference between oxygen tension of normal and of ischaemic tissues as measured by two electrodes*

\begin{tabular}{|c|c|c|c|c|c|c|c|}
\hline \multirow{2}{*}{$\begin{array}{c}\text { Electrode } \\
\text { number }\end{array}$} & \multirow{2}{*}{$\begin{array}{l}\text { Number } \\
\text { of expt's }\end{array}$} & \multirow{2}{*}{$\begin{array}{l}\text { Number } \\
\text { of det's }\end{array}$} & \multirow{2}{*}{$\begin{array}{l}\text { Relative } \\
\text { position } \\
\text { of foot }\end{array}$} & \multicolumn{3}{|c|}{ Mean galvanometric readings } & \multirow{2}{*}{$\begin{array}{c}\text { Standard } \\
\text { deviation of } \\
\text { difference-mean }\end{array}$} \\
\hline & & & & Normal & Ischaemic & Diff. & \\
\hline $\begin{array}{l}2 \\
3 \\
2 \\
3 \\
2 \\
3\end{array}$ & $\begin{array}{l}10 \\
10 \\
10 \\
10 \\
10 \\
10\end{array}$ & $\begin{array}{l}40 \\
40 \\
24 \\
24 \\
10 \\
10\end{array}$ & $\begin{array}{l}\text { level } \\
\text { level } \\
\text { lowered } \\
\text { lowered } \\
\text { raised } \\
\text { raised }\end{array}$ & $\begin{array}{c}10 \\
8.8 \\
9.7 \\
8.4 \\
9.5 \\
8.6\end{array}$ & $\begin{array}{l}3.9 \\
4.2 \\
6.7 \\
5.0 \\
3.1 \\
3.5\end{array}$ & $\begin{array}{l}6.1 \\
4.6 \\
3.0 \\
3.4 \\
6.4 \\
5.1\end{array}$ & $\begin{array}{l}1.0 \\
0.7 \\
1.8 \\
1.1 \\
2.2 \\
1.4\end{array}$ \\
\hline
\end{tabular}

* The oxygen tension was significantly higher $(\mathrm{P}=<5 \%)$ in the normal than in the ischaemic foot except in the case of electrode Number 2 when used in the lowered foot.

in this Journal (16). The apparatus consists of a platinum cathode, a relatively simple circuit, variable resistances and meters to control and measure voltage and current, and a calomel half cell as an anode.

At voltage 0.4 to 0.8 current varies linearly with oxygen tension at the electrode tip. In the present study each result is reported as a percentage difference of current from that obtained in the horizontal position.

Room temperature and skin temperatures at electrode sites were recorded just before each change in position. Galvanometric readings from each electrode were taken every two minutes. In order to make certain that each electrode was responsive, oxygen was briefly administered by inhalation and the response in galvanometric readings noted.

In the case of the normal subjects and of six of the patients, the readings were then continued with the subject for twenty minutes in each of the following positions: horizontal, foot of table lowered 7 inches, horizontal, lowered 7 inches, horizontal, foot of table raised 7 inches, and horizontal. This 7 inch deviation from the horizontal entails a hydrostatic pressure difference of 4 to 5 inches between the right atrium and toe. In six other patients, after the initial twenty minute control period, the footdown position was maintained for two hours. They were then returned to the horizontal for a final twenty minutes. In these prolonged experiments no foot-up position was used.

Fourteen patients with severe peripheral arteriosclerosis with occlusion were studied. Their ages ranged from 52 to 80 years. Twelve were males, two females. Five were diabetic, and in two cases a lumbar ganglionectomy had been performed. On completion of a heat reflex vasodilatation test in a $20^{\circ} \mathrm{C}$. constant temperature room the skin temperature at the base of the toes averaged $25.7^{\circ} \mathrm{C}$. (range 20.2 to $28.6^{\circ} \mathrm{C}$.). The average temperature under these conditions in the normal toe is $31^{\circ} \mathrm{C}$. Two of the electrodes were used throughout all experiments. The average of the galvanometric readings with these electrodes in the ischaemic feet in any one position was much less than the average in normal feet in the same position (Table I). Further evidence of the severity of the arterial occlusion is given by the slowness with which inhaled oxygen was detectable in the toes. In the normals the oxygen tension increased by 144 per cent (average) within two minutes, whereas in the ischaemic limbs it increased by 11 per cent (average). This delay in the abnormal limbs is seen in normals only when there is severe vasoconstriction (17). The eight normal subjects, six female and two male, ranged in age from 16 to 48 years.

In an attempt to learn whether the increased venous pressure incident to the foot-down position might account for the oxygen tension changes observed, experiments were conducted in which venous pressure was raised by a pressure cuff on the ankle. Two patients and two normal subjects were studied in the horizontal position. After a twenty minute study, a cuff pressure of $13 \mathrm{~mm}$. $\mathrm{Hg}$ was maintained for twenty minutes. This sequence was then repeated. Skin oxygen tension and temperature were recorded as before.

\section{RESULTS}

In patients and normals, significant increases of oxygen tension were observed in the foot-down position (Table II). The increases were greater, both relatively and absolutely, in patients (average 13 per cent) than in normals (average 4 per cent). When the foot-down position of patients was main-

TABLE II

Changes in cutaneous oxygen tension in feet resulting from changes in position*

\begin{tabular}{|c|c|c|c|c|}
\hline $\begin{array}{l}\text { Position } \\
\text { of foot }\end{array}$ & $\begin{array}{l}\text { Number } \\
\text { of expt's }\end{array}$ & $\begin{array}{l}\text { Number } \\
\text { of det's }\end{array}$ & $\begin{array}{l}\text { \% Mean diff. } \\
\text { in } \mathrm{O}_{2} \text { tension } \\
\text { from } \\
\text { horizontal }\end{array}$ & $\begin{array}{l}\text { Standard } \\
\text { deviation }\end{array}$ \\
\hline $\begin{array}{l}\text { Lowered } 20 \text { mins. } \\
\text { Normal } \\
\text { Ischaemic }\end{array}$ & $\begin{array}{l}6 \\
6\end{array}$ & $\begin{array}{l}47 \\
39\end{array}$ & $\begin{array}{l}+4 \\
+13\end{array}$ & $\begin{array}{l}.16 \\
.17\end{array}$ \\
\hline $\begin{array}{l}\text { Lowered } 120 \text { mins. } \\
\text { Ischaemic } \\
\text { Raised } 20 \text { mins. }\end{array}$ & 6 & 44 & +22 & .16 \\
\hline $\begin{array}{l}\text { Normal } \\
\text { Ischaemic }\end{array}$ & $\begin{array}{l}6 \\
6\end{array}$ & $\begin{array}{l}47 \\
34\end{array}$ & $\begin{array}{c}\text { insignificant } \\
-22\end{array}$ & $\begin{array}{l}.15 \\
.25\end{array}$ \\
\hline
\end{tabular}

* A significant change $(P=<5 \%)$ in oxygen tension is noted in all cases except in raising a normal extremity for 20 minutes. 
tained for two hours, rather than for twenty minutes, there were further increases in oxygen tension, and on return to the horizontal position the oxygen tension decreased promptly and completely. The foot-up position resulted in significant decreases in oxygen tension in the case of the patients (average 22 per cent), but in the case of normals no significant change in oxygen tension resulted. In the patients pain usually occurred when the legs were elevated but never in the case of normals.

The temperature measurements of skin showed no statistically significant change in blood flow in any series of experiments.

When a pressure cuff $(13 \mathrm{~mm}$. $\mathrm{Hg}$, or 7 inches water) was used on the ankles of four subjects, no statistically significant changes in oxygen tension or skin temperature resulted.

\section{DISCUSSION}

The increase in oxygen tension of the skin of the feet when dependent and its decrease on elevation may result from slight changes in blood flow, although blood flow changes were not detectable by the skin temperature measurements. It is possible that part of the oxygen tension changes were caused by capillaries being more distended in the dependent position and collapsed in the elevated position. The distension might facilitate the passage of oxygen to the tissue. However, we could demonstrate no change in oxygen tension, in the horizontal position, resulting from a cuff pressure of 7 inches of water $(13 \mathrm{~mm} . \mathrm{Hg})$. It is possible that this small cuff pressure reduced blood flow (18) (but we were unable to detect it), that transfer of oxygen from the blood to the tissues was facilitated, and that the two opposing effects explain the lack of change of oxygen tension in the cuff experiments.

All the methods of measuring blood flow have some disadvantage when used in measuring posturally-induced changes. Oxygen content of venous blood returning from a limb may fail to show the state of the most severely ischaemic $(12,14)$ part, since the sampling must be from the larger vessels far proximal to that part. Skin temperature measurement $(9,10,13)$ at reasonably constant room temperature is an indication of blood flow at the spot being observed, but by this method we were unable to demonstrate changes in flow in the present experiments. Pulse wave plethysmog- raphy is completely unsuitable as an index of change in blood flow induced by change in posture (8). Cuff-plethysmography is difficult or impossible when the capacity vessels are full (19), as in the dependent position. In the elevated position, especially in limbs made ischaemic by arterial occlusion, great care must be taken to avoid interference with flow. We know of no measurements of posturally-induced circulation changes by calorimeter and believe that they would be open to the same criticism as that made of skin temperature measurements.

We think that the change in nutrition of ischaemic tissues brought about by change in posture is shown better by these measurements of oxygen tension than by measurements of blood flow.

\section{SUMMARY}

Twelve patients with ischaemic feet and six normal individuals were tilted for twenty minutes from the horizontal position to the 7 inch foot-down position, and for the same period of time to the 7 inch foot-up position. The cutaneous oxygen tension at the base of the ischaemic toes was found to be much less than that in the toes of normal subjects.

On lowering the ischaemic feet, there was an average increase of oxygen tension of 13 per cent, and on elevating them from the horizontal, a decrease of 22 per cent. In normal individuals there was a slight increase of oxygen tension upon lowering the feet, and no significant change on raising the feet. The increases in oxygen tension were maintained or further increased in the toes of patients who remained for two hours in the foot-down position.

The changes in oxygen tension incident to change in position may have resulted from undetected changes in blood flow, from changes in effective capillary surface, or from other factors. There is no reason to suppose that they resulted from changes in cutaneous oxygen utilization. A foot-down position of this degree increases the oxygen, and presumably other hematogenous substances, available to the skin. This may explain the relief of pain and the improvement in skin color that often result from placing an ischaemic foot in a somewhat dependent position, and gives an objective reason for using the dependent position of the foot therapeutically. 


\section{REFERENCES}

1. Montgomery, H., and Starr, I., Four physiotherapeutic devices for the treatment of peripheral vascular disorders. Am. J. M. Sc., 1939, 197, 485.

2. Pearse, H. E., Jr., and Morton, J. J., The blood pressure in the arteries of the extremities in normal subjects and in patients with peripheral vascular disease. Am. J. M. Sc., 1932, 183, 485.

3. Hickam, J. B., McCulloch, R. P., and Reeves, R. J., Normal and impaired function of the leg veins. Am. Heart J., 1949, 37, 1017.

4. Henry, J. P., Effects of temperature and exercise on venous pressure in the foot when in the erect posture. Am. J. Med., 1948, 4, 619.

5. Pollack, A. A., and Wood, E. H., Venous pressure in the human leg during exercise and in various positions. Federation Proc., 1948, 7, 94.

6. Burch, G. E., A Primer of Venous Pressure, Philadelphia, Lea \& Febiger, 1950.

7. Walker, A. J., and Longland, C. J., Venous pressure measurement in the foot in exercise as an aid to investigation of venous disease in the leg. Clin. Sc., 1950, 9, 101.

8. Edholm, O. G., Howarth, S., and Sharpey-Shafer, E. P., Resting blood flow and blood pressure in limbs with arterial obstruction. Clin. Sc., 1951, 10, 361.

9. Roth, G. M., Williams, M. M. D., and Sheard, C., Changes in the skin temperatures of the extremities produced by changes in posture. Am. J. Physiol, 1938, 124, 161.

10. Nielsen, M., Herrington, L. P., and Winslow, C.-E. A., The effect of posture upon peripheral circulation. Am. J. Physiol., 1939, 127, 573.
11. Wilson, G. M., The blood flow to the lower limbs in peripheral arterial disease and coarctation of the aorta. Edinburgh M. J., 1951, 58, 125.

12. Wilkins, R. W., Halperin, M. H., and Litter, J., The effect of the dependent position upon blood flow in the limbs. Circulation, 1950, 2, 373.

13. Youmans, J. B., Akeroyd, J. H., Jr., and Frank, H., Changes in the blood and circulation with changes in posture. The effect of exercise and vasodilatation. J. Clin. Invest., 1935, 14, 739.

14. Goldschmidt, S., and Light, A. B., A cyanosis, unrelated to oxygen unsaturation, produced by increased peripheral venous pressure. Am. J. Physiol., 1925, 73, 173.

15. Davies, P. W., and Brink, F., Jr., Microelectrodes for measuring local oxygen tension in animal tissues. Rev. Scient. Instruments., 1942, 13, 524.

16. Montgomery, $\mathrm{H}$., and Horwitz, O., Oxygen tension of tissues by the polarographic method. I. Introduction: Oxygen tension and blood flow of the skin of human extremities. J. Clin. Invest., 1950, 29, 1120.

17. Penneys, R., and Montgomery, H., Oxygen tension of tissues by the polarographic method. V. The rate of movement of oxygen from the peripheral artery to the skin. J. Clin. Invest., 1952, 31, 1042.

18. Halperin, M. H., Friedland, C. K., and Wilkins, R. W., The effect of local compression upon blood flow in the extremities of man. Am. Heart J., 1948, 35, 221.

19. Greenfield, A. D. M., and Shepherd, J. T., A quantitative study of the response to cold of the circulation through the fingers of normal subjects. Clin. Sc., 1950, 9, 323. 